\title{
Band neutrophil sign: corroborative case of a new pathognomonic finding
}

\author{
Ana Mesquita Varejão, ${ }^{1}$ Carla Ramalho ${ }^{2,3}$
}

'Obstetrics and Gynecology, Pedro Hispano Hospital, Matosinhos, Portugal ${ }^{2}$ Center of Prenatal Diagnosis, Department of Obstetrics, University Hospital Center of São João, Porto, Portugal ${ }^{3}$ Faculty of Medicine, University of Porto, Porto, Portugal

\section{Correspondence to} Dr Ana Mesquita Varejão; anabarbara.varejao@gmail.com

Accepted 10 June 2021

\section{DESCRIPTION}

A 34-year-old G2P1, with no relevant medical history, had an increased risk of trisomy 21 on first trimester combined screening. Ultrasound at 12 weeks' gestation showed a normal nuchal translucency, present nasal bone and increased ductus venosus pulsatility index. Furthermore, no obvious stomach image was visualised, and a large cystic image was detected occupying most of the fetal abdomen and pelvis, resembling the C-shape loop described as the 'band neutrophil sign' by Ivanitskaya $e t a l,{ }^{1}$ as shown in the presented figure 1 . Chorionic villus sampling was performed at 14 weeks, and genetic results came out positive for trisomy 21. The patient decided to undergo a termination of pregnancy. Autopsy revealed distended stomach, incomplete intestinal rotation and combined duodenal and oesophageal atresia.

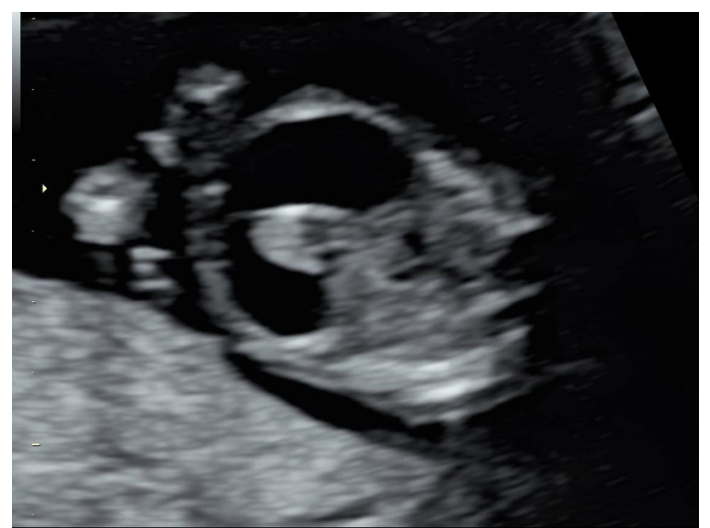

Figure 1 First trimester ultrasound — large cystic image occupying most of the fetal abdomen and pelvis, resembling the C-shape loop described as the 'band neutrophil sign'.

\section{Learning points}

- 'Band neutrophil sign' is a new pathognomonic sign of combined duodenal and oesophageal atresia, regardless of the presence of tracheoesophageal fistula.

- 'Band neutrophil sign' is described as a cystic symmetrical C-shaped loop occupying a central position in the fetal abdomen close to the anterior abdominal wall.

These findings come to corroborate the study of Ivanitskaya et al $^{1}$ when describing this first trimester ultrasound new marker for combined duodenal and oesophageal atresia, named 'band neutrophil sign'. This is a first trimester specific marker, characterised by a symmetrical C-shaped loop occupying most of the fetal abdomen in a central position and close to the anterior abdominal wall. Our case contributes to enhance the importance and relevance of this pathognomonic sign for the diagnosis of combined duodenal and oesophageal atresia, regardless of the presence of tracheoesophageal fistula.

Contributors AMV was responsible for the conception and design of the work. CR was responsible for scientific revision and for approving the final version for publication.

Funding The authors have not declared a specific grant for this research from any funding agency in the public, commercial or not-for-profit sectors.

Competing interests None declared.

Patient consent for publication Obtained.

Provenance and peer review Not commissioned; externally peer reviewed.

\section{REFERENCE}

1 Ivanitskaya O, Odegova N, Shchapov N, et al. Band neutrophil sign: a strong first-trimester ultrasound marker of combined duodenal and esophageal atresia. Prenat Diagn 2020. doi:10.1002/pd.5848. [Epub ahead of print: 17 Oct 2020]. 
Images in...

Copyright 2021 BMJ Publishing Group. All rights reserved. For permission to reuse any of this content visit https://www.bmj.com/company/products-services/rights-and-licensing/permissions/

BMJ Case Report Fellows may re-use this article for personal use and teaching without any further permission.

Become a Fellow of BMJ Case Reports today and you can:

- Submit as many cases as you like

- Enjoy fast sympathetic peer review and rapid publication of accepted articles

Access all the published articles

Re-use any of the published material for personal use and teaching without further permission

Customer Service

If you have any further queries about your subscription, please contact our customer services team on +44 (0) 2071111105 or via email at support@bmj.com.

Visit casereports.bmj.com for more articles like this and to become a Fellow 